Jurnal Akuntansi dan Investasi, Vol. 17 No. 2, Hlm: 186-196, Juli 2016

Artikel ini tersedia di website: http://journal.umy.ac.id/index.php/ai

DOI: $10.18196 /$ jai.2016.0054.186-196

\title{
Konsep Pendidikan Karakter Keagamaan Untuk Calon Akuntan: Studi Kasus di Program Studi Akuntansi Universitas Muhammadiyah Yogyakarta
}

Juanda* \& Hafiez Sofyani

Prodi Akuntansi Universitas Muhammadiyah Yogyakarta, Jln. Lingkar Selatan, Kasihan, Bantul, D. I. Yogyakarta

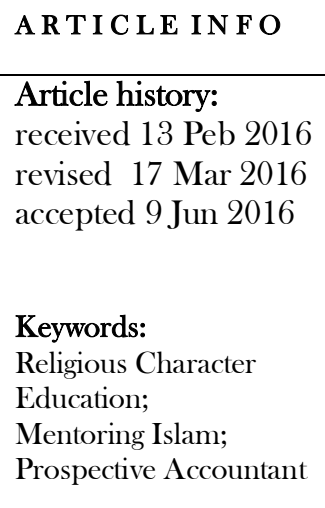

\begin{abstract}
A B S T RACT
This paper describes the concept of religious character education organized for students in Accounting (prospective accountant) at the Universitas Muhammadiyah Yogyakarta (UMY). The program is named Pendampingan Agama Islam (PAI). This paper explain the weaknesses and suggest improvements to the concept of PAI which has been run previously in UMY. This paper also presents various aspects of religious character education in Islamic perspective, such as: the design stage of activities, material formulation and execution model of the program. This paper is expected contributing in the formulation of the concept of education that is based on Islamic values, typically in the university environment, and as a reference literature for the development of educational studies of religious character, especially to the prospective accountant.
\end{abstract}

(C) 2016 JAI. All rights reserved

\section{PENDAHULUAN}

Pendidikan etika, khususnya mahasiswa program studi akuntansi (dibaca: calon akuntan) menjadi kajian yang menyita banyak perhatian dari akademisi, khususnya setelah berbagai kasus tidak etis akuntan dalam pelaporan keuangan terbongkar (Weber, 2006). Merespon kasus-kasus yang terjadi tersebut, para pemerhati isu etika bisnis semakin gencar untuk melakukan penelitian dan pengembangan terkait pendidikan etika, khususnya etika profesi akuntan yang memiliki peran vital di lingkungan bisnis. Salah satu penelitian telah dilakukan oleh Meyhew dan Murphy (2009) yang menemukan bahwa akuntan -diperankan oleh mahasiswa dalam desain eksperimenya- yang menempuh pendidikan etika memiliki perilaku lebih etis dibandingkan dengan akuntan yang tidak menempuh pendidikan etika. Hasil penelitian ini kemudian dijadikan salah satu alasan kuat perlunya pendidikan etika bagi para akuntan.

Pendidikan etika sendiri merupakan salah satu dari tanggungjawab perguruan tinggi selaku pencetak calon akuntan. Di tengah wajibnya pendidikan etika bisnis diajarkan di berbagai perguruan tinggi, nyatanya kasus-kasus perilaku curang akuntan baik yang terungkap media maupun yang tidak, masih kerap terjadi. Hal ini mengindikasikan bahwa pendidikan etika bisnis tidak dapat menjamin seseorang untuk berperilaku etis ketika berada di lingkungan kerja. Alasan yang mungkin menjelaskan kenapa pendidikan etika "tidak cukup berhasil" menjadikan peserta didiknya bersikap etis bisa jadi karena pendidikan etika di pendidikan tinggi dinilai sangat terlambat dan juga tidak cukup untuk dapat memapankan kesadaran etis peserta didik (Amernic dan Craig 2004; Fisher et al., 2007; Low et al., 2008). Selain alasan tersebut, bisa jadi dalam konteks pendidikan di lingkungan universitas secara intra kurikuler, sosialisasi dan internalisasi nilai-nilai etika hanya sebatas konsep kognitif saja (Akhwan, 2014) dan tidak diikuti dengan penjiwaan yang mendalam. Hal tersebut tentu menjadi isu menarik untuk dikaji.

Dari keterbatasan pendidikan etika dalam mempengaruhi perilaku etis seseorang, Sofyani dan Pramita (2013) menyarankan agar memperhatikan aspek fundamental lain yang berasosiasi dengan perilaku etis seseorang, yakni aspek religiusitas yang ditumbuhkan melalui pendidikan karakter keagamaan (lihat juga: Triyuwono, 2012; Mazereeuw et al., 2014). Hal ini sejalan dengan argumentasi yang dijelaskan oleh Ajzen dan Fishbein (2005) dalam teorinya, yaitu Teori Perilaku yang Direncanakan (Planned Behavior Theory). Menurut pandangan Ajzen dan Fishbein (2005) anteseden seseorang dalam berperilaku adalah niat. Niat berperilaku ini dipengaruhi oleh sikap dalam berperilaku yang merupakan fungsi dari keyakinan keberperilakuan 
(behavioral beliefs) yang sejatinya dipengaruhi oleh komitmen religius yang diyakini atau dianut oleh seseorang tersebut (lihat juga: Fishbein dan Ajzen, 1974; 1975; Jones, 1991; Cohen dan Bennie, 2006). Sehingga, nilai keagamaan (religioun) dapat menjadi landasan dalam bersikap dan berperilaku. Penjelasan ini mengindikasikan bahwa proses pembuatan keputusan etis memiliki keterkaitan dengan nilainilai yang diyakini seseorang sebelum akhirnya orang tersebut berada pada tahap akhir, yakni melakukan aksi perilaku etis saat menghadapi dilema etika.

Dalam konteks pendidikan di lingkungan Universitas Muhammadiyah Yogyakarta, pendidikan karakter keagamaan (Islam) yang di dalamnya juga meliputi pendidikan akhlak dan etika sebenarnya telah diselenggarakan cukup lama dalam bentuk mata kuliah maupun bentuk lainnya. Hanya saja, konsep pengajaran ajaran Islam ini masih bersifat formalistik dan cenderung mengarah pada sistem pendidikan yang berorientasi kognitf, namun aspek lainya, seperti: afektif, psikomotorik, softskill dan aspek non-akademik lainnya yang berkaitan dengan pembentukan moral masih belum disentuh secara mendalam (Juanda, 2004; Akhwan, 2014). Masalah ini selanjutnya menggiring terjadinya dekadensi moral, baik dalam pergaulan, kepribadian, maupun pemahaman keagamaan. Sebagai contoh, mayoritas ummat Islam mengerti bahwa berjudi itu hukumnya dilarang (dibaca: Haram) namun banyak ummat Islam yang mengetahuinya tetap melakukan larangan tersebut. Dalam konteks bisnis juga demikian, misalnya Majelis Ulama Indonesia (MUI) telah menfatwakan haram bunga karena termasuk riba, namun banyak ummat muslim masih berhubungan dengan bunga ini (MUI, 2004). Berangkat dari hal ini, maka perlu dikembangkan suatu program internalisasi nilai-nilai Islam yang bersifat intra-kurikuler dalam bentuk yang tidak hanya mengedepankan aspek kognitif saja, tetapi juga aspek-aspek lain yang berhubungan dengan moralitas secara berimbang. Program pendidikan nilai-nilai dan karakter Islami yang dimaksud selanjutnya dikemas dalam bentuk Pendampingan Agama Islam (PAI).

Secara umum, tujuan perumusan konsep PAI ini adalah untuk mengembangkan sikap dan pola pikir ke-Islam-an mahasiswa selaku calon akuntan menuju pemahaman Islam yang kaffah dengan polapola pendekatan cara belajar mahasiswa aktif. Nilainilai Islam yang dipelajari ini diharapkan akan semakin kuat tertanam dalam sanubari setiap mahasiswa. Dari pemahaman yang mendalam inilah mahasiswa sebagai calon akuntan diharapkan akan terdorong untuk mengamalkan nilai-nilai religius yang Islami dalam kehidupan sehari-hari, sehingga perilaku mahasiswa selaku calon akuntan akan lebih etis, tidak hanya ketika menjadi mahasiswa saja, tetapi juga sampai mereka bekerja secara nyata sebagai akuntan di kemudian hari.

Dari paper ini diharapkan dapat memberikan sumbangsih mengenai konsep pendidikan karakter keagamaan Islam yang syarat dengan nilai etis untuk calon akuntan di lingkungan perguruan tinggi. Selain itu, dari paper ini dapat memberikan kontribusi dalam bentuk literatur riset karena masih jarangnya riset terkait isu etika yang diasosiasikan dengan religiusitas. Paper ini juga diharapkan dapat dijadikan bahan acuan atau rujukan bagi akademisi, khususnya dalam pengembangan Islamisasi ilmu pengetahuan yang tidak hanya berfokus pada aspek kognitif, tetapi juga afektif, prikomotorik, dan moralitas.

\section{TINJAUAN LITERATUR DAN FOKUS PAPER}

\section{Fungsi dan Tujuan Pendidikan}

Fungsi dan tujuan pendidikan ada dua perspektif (sudut pandang), pertama fungsi dan tujuan perspekstif secara umum, dalam hal ini menurut Undang-undangan RI tahun 2003 dan kedua perspektif menurut ahli pendidikan Islam. Menurut Undang-Undang RI tahun 2003 tentang sistem pendidikan nasional, dideskripsikan bahwa fungsi pendidikan adalah untuk mengembangkan kemampuan dan membentuk watak serta peradaban bangsa yang bermartabat dalam rangka mencerdaskan kehidupan bangsa. Dari beberapa pandangan tentang fungsi pendidikan secara umum adalah bahwa ada dua fungsi yang paling mendasar, yaitu peningkatan kualitas pribadi dan kualitas sosial. Peningkatan kualitas pribadi menyangkut kemampuan intelektual, ketrampilan, kepribadian dan lain-lain. Kualitas sosial menyangkut integrasi sosial, transmisi dan lain-lain. Kualitas sosial menyangkut integrasi sosial, transmisi kebudayaan dan mutu kehidupan.

Sedangkan fungsi dan tujuan menurut perspektif pendidikan Islam, menurut Omar Mohammad Al-Toumy Al Syaibani, profesor falsafah pendidikan Tripoli, membagi tujuan pendidikan menjadi dua, yaitu tujuan individual dan tujuan sosial. Tujuan pendidikan individu meliputi (Juanda, 2004):

(1) Tempat pembinaan keimanan

(2) Pembinaan Akhlak

(3) Pembinaan kesehatan fisik

(4) Pembinaan kesehatan mental

(5) Pembinaan kemampuan penguasaan ilmu pengetahuan 
(6) Pembinaan seni dan apresiasi terhadap kesenian

(7) Penyaluran bakat dan hobi untuk mengisi waktu luang

(8) Pembinaan kesadaran sosial, ekonomi dan politik

(9) Pembinaan kesadaran untuk menghargai kepentingan keluarga

Tujuan pendidikan sosial meliputi:

(1) Memperkokoh kehidupan spiritual masyarakat

(2) Mencapai kebangkitan ilmiah, kebudayaan dan kesenian

(3) Meneguhkan bahasa Arab

(4) Mewujudkan masyarakat Islam yang mulia

(5) Pembinaan masyarakat yang kuat dan maju dalam bidang ekonomi

(6) Pembinaan masyarakat Islam yang kuat dan bersatu

(7) Mewujudkan perdamaian dunia

(8) Meninggikan proses pendidikan

Al-Abrasy membagi tujuan pendidikan Islam menjadi empat butir, yaitu:

(1) Pembinaan akhlak

(2) Menyiapkan anak didik untuk hidup di dunia dan akherat

(3) Penguasaan bekerja dalam masyarakat (LP3UMY, 1999)

Dari uraian di atas, perbedaan fungsi dan tujuan pendidikan secara umum dengan ahli pendidikan Islam terletak pada tata nilai yang digunakan. Pendidikan secara umum didasari nilai-nilai positif dengan penekanan pada intelektualitas untuk pengembangan ilmu dan kehidupan duniawi semata. Sedangkan pendidikan Islam didasari pada tata nilai Islam yang mengintegrasikan aspek-aspek kemanusiaan dengan keilahian (hablum minallah dan habum minanas).

\section{Konsep Pendidikan Karakter Menurut 'Ulama Islam}

Pendidikan karakter mempunyai makna lebih tinggi dari pendidikan moral. Pendidikan karakter tidak hanya sekedar mengajarkan mana yang benar dan mana yang salah, tetapi lebih dari itu. Pendidikan karakter menanamkan kebiasaan (habituation) tentang hal yang baik sehingga peserta didik menjadi paham tentang yang baik dan yang salah (domain kognitif), mampu merasakan nilai yang baik (domain afektif) dan biasa melakukannya (domain perilaku). Dengan demikian pendidikan karakter berkaitan dengan dengan pembiasaan yang terus-menerus dilakukan (Khilmiyah, 2013).

Pendidikan karakter Islami bagi mahasiswa sejatinya merupakan bagian dari konsep ekonomi Islam dan Islamisasi ilmu pengetahuan yang bertujuan mendatangkan falah (kesejahteraan/ kebahagiaan hidup di dunia dan akhirat). Hal ini sejalan dengan pendapat beberapa akademisi bahwa ekonomi Islam didasarkan sekurang-kurangnya pada tiga aspek, yakni: keyakinan (Aqidah), hukum (Syariah), dan sikap dan perilaku (Akhlak) (lihat: Arif, 1985; Triyuwono, 2012; Yaya et al., 2014). Mengacu pada paradigma ini, diyakini bahwa ilmu memiliki keterkaitan dengan nilai ajaran tertentu yang tidak dapat dipisahkan satu dengan yang lainnya. Dalam konteks keIslaman, maka variabel atau aspek lain yang berasosiasi dengan ilmu adalah ajaran agama yang sampai kepada manusia melalui wahyu dari tuhan, yaitu Allah SWT.

Abu Sulaiman menjelaskan bahwa Allah SWT memang telah menganugerahkan akal bagi manusia sebagai bekal untuk mencari ilmu pengtahuan dalam rangka menggali berbagai aspek agar dapat menjalankan tugasnya menjadi pemakmur dunia (khalifah fil Ardhi). Sementara, ajaran agama yang datang melalui wahyu adalah informasi yang bersumber dari Allah SWT dari alam ghaib (metafisik) yang menjelaskan tentang tuntunan dan batasan mengenai segala hal yang harus dilakukan dan harus dijauhi agar manusia mampu meraih kesuksesan dalam pelaksanaan tugasnya di dunia sebagai khalifah fil Ardhi (P3EI, 2009). Jika manusia hanya mengandalkan akal atau ilmu pengetahuan, maka tidak akan dapat berhasil mencapai orientasinya, yakni falah (kesejahteraan/kebahagiaan di dunia dan akhirat). Hal itu dikarenakan akal manusia tidak memiliki cukup kemampuan untuk mencari informasi mengenai bagaimana cara agar tugasnya di dunia dapat berhasil dilaksanakan dan akhirnya dapat mencapai falah. Jika manusia tidak berpegang kepada wahyu, maka manusia akan rentan untuk tersesat dan terjebak pada suatu pandangan atau dugaan yang keliru. Misalnya, manusia yang hanya mengandalkan akal atau pengetahuan bisa jadi merasa berbuat kebaikan, padahal dia melakukan kerusakan, sebagaimana yang disampaikan Allah SWT. Dalam Al-Qur'an surat Al-Baqarah [2]: ayat 11 dan 12:

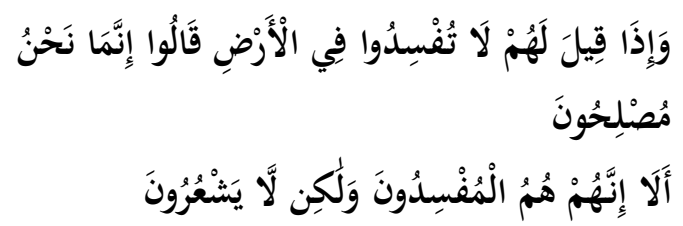


Artinya:

"Dan bila dikatakan kepada mereka (Manusia): "Janganlah kamu membuat kerusakan di muka bumi". Mereka (mansia) menjawab: "Sesungghunya kami mengadakan perbaikan”.

"Ingatlah, sesungguhnya mereka itulah orangorang yang membuat kerusakan, tetapi mereka tidak sadar".

Dari argumen di atas maka sangat jelas bahwa pendidikan karakter keagamaan pada diri seseorang, khususnya calon akuntan, menjadi hal penting untuk dijalankan supaya para calon akuntan dibekali pemahaman, nilai yang menjiwa dan menjiwai, dan aktivitas religius yang dapat menggiring kepada falah (kese-jahteraan/kebahagiaan hidup di dunia dan akhirat). Sebagai ilustrasi, seorang akuntan yang hanya menu-ruti keinginannya (self interest) akan berfikir bahwa dengan melakukan manipulasi laporan keuangan, maka dia akan mendapatkan keuntungan berupa insentif, misalnya dalam kasus budgetary slack (Merchant, 1985; Dunk, 1993; Stevens, 2002). Pada kasus ini, akuntan tersebut mengira ketika nantinya benar-benar mendapatkan insentif hasil dari mela-kukan budgetary slack, maka akuntan tersebut akan berbahagia. Padahal, perilaku yang akuntan tersebut lakukan bisa saja membawa kepada keterpurukan ketika diketahui oleh pimpinan, dan tidak menutup kemungkinan akuntan tersebut dikeluarkan dari tem-pat kerja. Selain itu, hal tersebut juga akan dimintai pertanggungjawaban di akhirat kelak atas segala perbuatannya melakukan budgetary slack untuk mendapatkan insentif dari perusahaan secara tidak halal (Triyuwono, 2012).

\section{Konsep Pendidikan dalalam Pendampingan Agama Islam di UMY}

Pendampingan Agama Islam merupakan prog$\mathrm{ram} /$ kegiatan transformasi nilai-nilai Islam (transfer of islamic values) yang sudah berlangsung cukup lama di lingkungan UMY. Internalisasi nilai-nilai keIslaman bersifat intra-kurikuler dan dapat dijadikan sarana dalam menampung aspirasi mahasiswa yang memiliki perhatian khusus terhadap pembinaan keagamaan yang belum terwujud di UMY, terutama dari segi afektif dan psikomotorik. Program Pendampingan Agama Islam yang pernah dilakukan telah dievaluasi sebelumnya oleh Juanda (2005). Dari hasil evaluasi tersebut, disimpulkan perlu adanya perbaikan pada kegiatan PAI, seperti pendamping, materi dan sistem kontrol agar tidak terkesan pendamping berjalan sendiri.

Selain sebagai transformasi nilai pendampingan ini sebagai kegiatan preventif dalam upaya mengatasi berbagai problem mahasiswa. Karena Pendam- pingan Agama Islam merupakan transfer nilai maka sudah barang tentu akan berhubungan juga dengan kecerdesan emosional (Emotional Quotient) dan kecerdasan spiritual (Spiritual Quotient). Kecerdasan emosi merupakan sebuah kecerdasan yang bisa memotivasi kondisi psikologis menjadi pribadipribadi yang matang; dalam bentuk kemampuan merasakan, memahami dan seara efektif menerapkan daya dan kepekaan emosi sebagai sumber energi, informasi dan pengaruh manusia.

Kecerdasan emosi lebih berpusat pada hubungan yang bersifat sosial, sementara ada dimensi lain yang tidak kalah pentingnya yaitu hubungan vertikal yang disebut dengan istilah kecerdasan spiritual (Spiritual Quotient). Marsha Sinetar dan Khalil Khavari menyampaikan definisi kecerdasan spiritual yang lebih sesuai dengan perkembangan definis kecerdasan spiritual yang lebih sesuai dengan perkembangan psikologi mutakhir. Menurut Sinetar (2000) "Kecerdasan spiritiual adalah pikiran yang mendapat inspirasi, dorongan dan efektivitas yang terinspirasi, theisness atau penghayatan Ketuhanan yang di dalamnya kita semua menjadi bagian”. Dari argumen di atas, maka perlu disusun suatu konsep pendidikan karakter kegamaan yang baru yang kemudian dirumuskan dalam suatu rumusan masalah:

RM: Bagaimana konsep pendidikan karakter keagamaan (Islam) untuk calon akuntan (mahasiswa akuntansi) di perguruan tinggi dengan mengacu kepada PAI yang sudah dilaksanakan di UMY?

\section{METODE PERUMUSAN KONSEP PROGRAM PENDAMPINGAN AGAMA ISLAM}

Paper ini bertujuan untuk merumuskan suatu konsep Pendidikan Agama Islam yang efektif untuk calon akuntan, dalam hal ini adalah mahasiswa program studi Akuntansi Universitas Muhammadiyah Yogyakarta (UMY). Efektif yang dimaksud di sini tidak hanya dalam arti proses belajar dapat terlaksana dengan baik secara administratif saja, tetapi juga dapat menginternalisasikan nilai Islam secara lebih intens kepada peserta didik. Model perumusan konsep ini menitik beratkan pada hasil pembelajaran (Learning Outcome) yang hendak dicapai. Secara spesifik, hasil pembelajaran tersebut meliputi tiga hal, yakni: pemahaman, pengamalan, dan penyebarluasan pemahaman. Secara jangka panjang, hasil pembelajaran diharapkan dapat menjadi penekan perilaku tidak etis para mahasiswa akuntansi (baca: calon akuntan) di masa mendatang (lihat Gambar 1). Perumusan PAI mengacu kepada program sejenis yang pernah dilaksanakan sebe- 
lumnya di lingkungan UMY dengan sedikit dibuat modifikasi perbaikan dan menyesuaikan dengan konteks permasalahan yang terjadi pada mahasiswa Akuntansi di masa kekinian. Modifikasi perbaikan ini dilakukan khususnya terkait konsep pelaksanaan dan materi yang diajarkan, dengan mengacu kepada pendapat ulama dan nash-nash dari Al-Qur'an serta dengan memasukkan saran dari berbagai pihak (Dekanat, Pimpinan Prodi Akuntansi, mahasiswa, dan dosen).
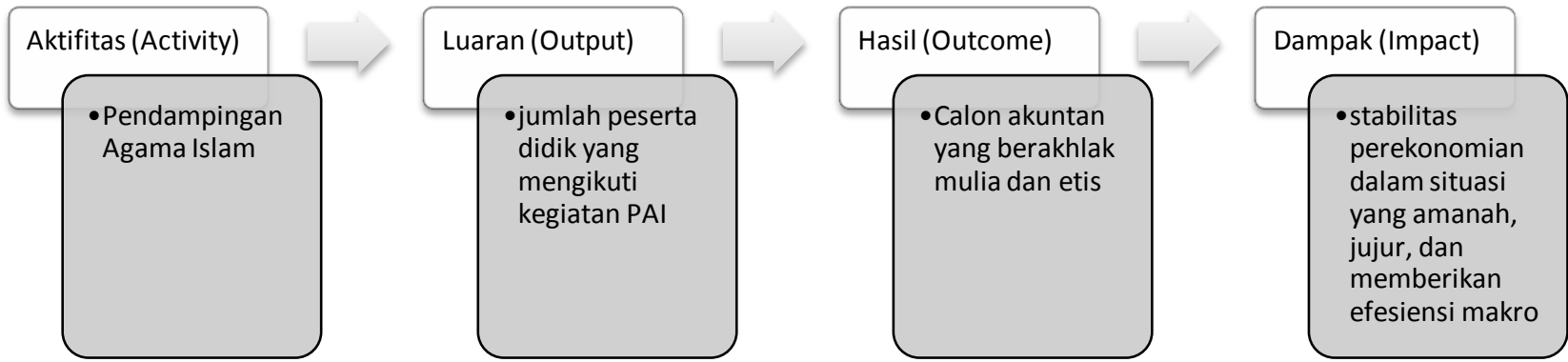

Gambar 1. Model Logika Capaian Pelaksanaan Program PAI

\section{Survey Permasalahan}

Dalam perumusan ini, terlebih dahulu dilakukan riset, yakni observasi lapangan dan wawancara kepada beberapa informan yang dinilai mengetahui informasi yang akan dicari tahu yakni terkait berbagai permasalahan perilaku mahasiswa Prodi Akuntansi UMY. Informan dalam survey permasalahan ini adalah para mahasiswa, dosen, dan himpunan mahasiswa prodi Akuntansi UMY. Survey ditujukan untuk mengetahui dan menganalisis permasalahan perilaku mahasiswa program studi Akuntansi UMY yang berkaitan dengan pelanggaran norma, etika, dan hukum Islam, baik yang secara langsung berkaitan dengan etika bisnis maupun tidak secara langsung berhubungan.

\section{Analisis Kelemahan Konsep PAI Sebelumnya}

Sebelum PAI baru dirumuskan, terlebih dahulu dilakukan analisis kelemahan dari program PAI sebelumnya yang telah dilaksanakan di level Universitas. Adapun hasil temuan dari analisis kelemahan PAI tersebut adalah sebagai berikut:

(1) Kekurangan pendamping. Idealnya dari 2.300 mahasiswa baru di UMY seharusnya membutuhkan pendamping 230 orang atau $10 \%$ dari jumlah peserta yang didampingi. Sementara, pendamping yang tersedia hanya 150 pendamping.

(2) Penguasaan materi dan metodologi pendamping kurang memadai.

(3) Kurang sosialisasi program Pendampingan Agama Islam. Hal ini mneyebabkan peserta yang hadir atau mengikuti kegiatan ini tidak $100 \%$.
(4) Penjadwalan yang tidak pasti. Hal ini menjadikan peserta didik kesulitan untuk mengikuti kegiatan dan akhirnya cenderung untuk malas dan mengabaikan PAI.

(5) Legalitas program Pendampingan Agama Islam dipertanyakan. Hal ini dikarenakan belum adanya koordinasi yang memadai antara Universitas dengan penyelenggara.

(6) Kurang respon dari Fakultas. Hal ini bisa jadi terkait dengan legalitas pelaksanaan program.

(7) Antusiasme mahasiswa dalam mengikuti progra PAI kurang, sehingga kehadiran mahasiswa kurang.

(8) Materi masih "melangit" dan belum menjawab problem yang dihadapi mahasiswa yang mengikuti PAI.

Berangkat dari kekurangan pada program PAI sebelumnya ini, maka dirumuskanlah suatu solusi yang diharapkan dapat memperbaiki PAI selanjutnya, yaitu:

(1) Penyesuaian jumlah pendamping PAI agar mencapai jumlah yang seimbang antara peserta didik dan pendamping. Hal ini bertujuan untuk memperlancar kegiatan PAI.

(2) Pendamping PAI diseleksi berdasarkan kapabilitas keagamaan dan skillnya. Selain itu diadakan pembekalan yang memadai bagi pendamping PAI agar kesiapan para pendamping PAI benar-benar baik. Pendamping PAI juga dipilih berdasarkan komitmennya dalam pelaksanaan kegiatan PAI.

(3) Adanya peningkatan koordinasi dan konsolidasi tim PAI dengan pihak rektorat maupun dekanat masing-masing fakultas. Hal ini agar terjalin komunikasi yang sejalan, sehingga luaran yang 
diharapkan dari kegiatan ini benar-benar tercapai.

(4) Pelaksanaan PAI pada semester awal sebagai tindak lanjut dari kegiatan Orientasi Studi Dasar Islam (OSDI). Hal ini bertujuan agar ada keberlanjutan pembinaan karakter pada peserta didik yang merupakan mahasiswa baru UMY.

(5) Sosialisasi kegiatan PAI lebih ditingkatkan dari semua sisi baik mahasiswa, dosen, dekanat dan rektorat.

(6) Idealnya pendamping sesuai dengan fakultas masing-masing agar pemikiran pemandu dan peserta PAI memiliki keselarasan.

(7) Materi kurikulum perlu diperbaiki, karena dianggap masih "melangit" dan belum menyentuh masalah-masalah kehidupan sehari-hari para peserta didik.

(8) Konsep pendampingan perlu diperbaik supaya lebih jelas dan mudah dilaksanakan baik oleh pendamping maupun peserta PAI.

\section{Perumusan Konsep PAI sebagai Pemecahan Masalah Keprilakuan Calon Akuntan}

Dari permasalahan perilaku yang diperoleh dari hasil observasi dan wawancara, selanjutnya dilakukan diskusi dengan pimpinan di lingkungan prodi Akuntansi dan Fakultas Ekonomi UMY, dalam hal ini adalah Ketua dan Sekretaris Prodi Akuntansi UMY dan perwakilan dari Dekanat Fakultas Ekonomi UMY. Diskusi dilakukan dalam rangka penyusunan strategi, program PAI, dan rangkaian kegiatan pendidikan karakter Islami. Perumusan PAI yang akan dilaksanakan juga mempertimbangkan kelemahan program PAI sebelumnya yang telah dipaparkan pada paragraf sebelumnya. Selanjutnya, detail pelaksanaan program dirumuskan oleh peneliti dengan berkonsultasi kepada beberapa pihak, yakni Ketua dan Sekretaris Prodi Akuntansi UMY, perwakilan dari Dekanat Fakultas Ekonomi UMY, dan tim pelaksana program PAI. Perumusan PAI juga merujuk kepada capaian luaran yang ingin dicapai dengan menyelaraskan dengan literaturliteratur yang bersumber dari Al-Qur'an dan $\mathrm{Al}$ Hadits mengenai argumentasi yang dapat menjadi alasan atas program apa yang sebaiknya dilaksanakan dalam program PAI.

\section{ISI DAN PEMBAHASAN}

\section{Temuan Permasalahan di Lingkungan Mahasiswa}

Permasalahan mahasiswa dalam hal perilaku, baik di dalam maupun di luar kampus adalah tang- gungjawab bersama dan lebih khusus diamanahkan kepada lembaga pendidikan. Oleh karenanya, perguruan tinggi sebagai lembaga pendidikan manusia dewasa dituntut untuk menyelanggarakan pendidikan yang tidak hanya berorientasi kepada pengetahuan, tetapi juga pada pengembangan karakter peserta didik agar terbentuk lulusan yang bebudi pekerti luhur. Di Universitas Muhammadiyah Yogyakarta, pengembangan karakter salah satunya diselenggarakan dengan program yang bernama Pendampingan Agama Islam (PAI). Konsep PAI ini dirancang dengaan mengacu kepada learning outcome yang ingin dicapai, yang sejatinya lebih menitikberatkan pada permasalahan perilaku yang diperoleh berdasarkan observasi, survey, dan wawancara yang dilakukan tim peneliti.

Adapun permasalahan yang ditemukan tersebut diantaranya adalah:

(1) Cara berpakaian yang tidak Islami; yakni adanya perilaku berpakaian yang mengarah kepada pengabaian norma-norma Islami dan syariah baik dilakukan oleh peserta didik laki-laki maupun perempuan. Untuk kasus laki-laki biasanya dalam bentuk menggunakan anting, bertatto, dan menggunakan celana robek yang menampakkan lutut (aurat bagi laki-laki). Sedangkan untuk perempuan biasanya dalam bentuk, mengenakan hijab tetapi menampakkan lekukan tubuh, bercelana ketat, mengenakan tata rias yang berebihan, dan mengenakan celana robek sehingga auratnya terlihat.

(2) Perilaku tidak baik dalam proses pembelajaran, seperti: datang terlambat, tidak mengerjakan tugas, membuat contekan, mencontek teman sesama peserta didik, dan melakukan plagiasi tugas kuliah.

(3) Dalam aspek perilaku berkaitan dengan bisnis yaitu tidak membayar belanjaan di warung kejujuruan.

(4) Untuk aspek perilaku lainnya adalah berlaku zalim, atau tidak berperilaku sesuai pada tempat dan kondisi tertentu. Contoh dari perilaku ini adalah merokok di kawasan dilarang merokok, membuang sampah sembarangan, meludah sembarangan, berfoto selfie berlebihan, aktif di media social secara berlebihan.

Berangkat dari temuan permasalahan-permasalahan tersebut, maka PAI dirancang dan dikemas dalam bentuk Mata Kuliah Pengembangan Diri dan karakter peserta didik yang dilandaskan pada nilainilai keIslaman yang luhur. Agar semua peserta didik mengikutinya, PAI dijadikan syarat mengikuti ujian skripsi, sehingga wajib diikuti seluruh mahasiswa 
program studi akuntansi. Diharapkan setelah mahasiswa mengikuti kegiatan ini, lulusan Program Studi Akuntansi mempunyai keunikan khusus pada nilainilai KeIslaman yang tertanam pada diri mereka. Dari sisi kompetensi hal ini akan menjadi nilai tambah bagi lulusan prodi Akuntansi UMY.

\section{MATERI PENDAMPINGAN AGAMA ISLAM} berikut:

Bentuk PAI yang dirancang adalah sebagai

(1) Recruitment Pendamping. Pendamping merupakan kakak angkatan/senior, diharapkan pendamping dari kakak angkatan agar dalam diskusi lebih akrab, posisi sebagai teman dalam menyelesaikan problem solving. Dalam penerimaan, syarat sebagai Pendamping adalah: lancar baca Al-Qur'an, wawasan keIslaman yang luas: ideologi yang tidak bertentangan dengan Islam, Perilaku/Akhlak: adab berpakaian, pergaulan, dan lain sebagainya.

(2) Stadium General ( $S G$ ), yaitu pemberian materimateri keIslaman oleh seorang nara sumber kepada para pendamping sebagai bekal sebelum dilaksanakan kegiatan PAI dalam satu kelompok besar dengan jadwal yang telah ditentukan. Kegiatan ini juga merupakan pembukaan secara resmi pelaksanaan PAI sekaligus menjelaskan tentang Pendampingan Agama Islam itu sendiri.

(3) Bentuk Halaqoh (kelompok kecil), yaitu bentuk forum dalam penyampaian materi adalah halaqoh (kelompok kecil melingkar), jumlah peserta 10-15 mahasiswa. Waktu pelaksanaan 100 menit dengan agenda: pembukaan, tilawah Al-Qur'an, penyampaian materi, diskusi dan penutup.

Adapun detil program PAI dari pertemuan pertama sampai kesepuluh adalah sebagai berikut:

\section{Pertemuan Pertama: Mengenal Jalanku (Ma'rifatul Islam)}

Tujuan dari sesi ini adalah mengenalkan Islam secara hoslistik maksudnya dalam memahami Islam tidak sekedar knowladge tetapi terintegrasi dengan nilai-nilai dalam perilaku kehidupan. Para peserta didik mengetahui dan memahami makna agama (dien) menurut Al-Qur'an, perbedaan agama Allah (dienullah) dan selain agama Allah (dien ghoirullah), dan mengetahui kesempurnaan Islam khususnya dalam kontek sebagai landasan dalam pengkajian ilmu pengetahuan, tidak terkecuali ilmu Akuntansi. Metode atau pendekatan dalam penyapaian materi dilakukan dengan pendekatan games, ceramah dan diskusi. Materi pokok yang disampaikan adalah: pengertian Al-Islam, karakteristik ajaran Islam dan Islam sebagai way of life. Dalam materi ini lebih menekankan pada aqidah Islam yang benar. Seluruh utusan Allah swt. Dari Adam as. Sampai dengan Nabi Muhammad saw. Risalah yang disampaikan sama yaitu aqidah Islam yang benar. Aqidah adalah dasar, fondasi mendirikan bangunan. Semakin tinggi bangunan yang akan didirikan, harus semakin kokoh fondasi yang dibuat (Ilyas, 2010). Seseorang yang memiliki aqidah yang kuat, pasti akan melaksanakan ibadah dengan tertib, memiliki akhlak yang mulia dan bermuamalat dengan baik (bidang akuntansi). Seseorang bisa saja merekayasa data atau berpurapura melaksanakan ajaran Islam, tapi Allah swt. Tidak akan memberi nilai kalau tidak dilandasi dengan aqidah yang benar. Allah berfirman dalam Al-Qur'an surat an Nahl [16] ayat 36:

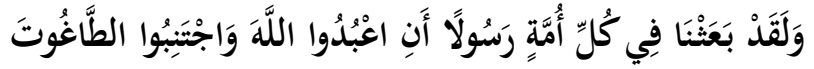

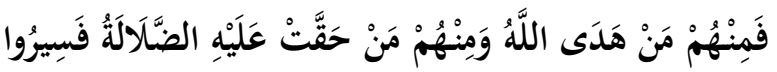

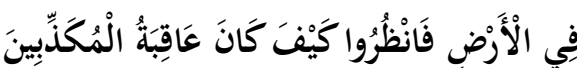 \\ Artinya: \\ "Dan sesungguhnya Kami telah mengutus rasul pada tiap-tiap umat (untuk menyerukan): "Sembahlah Allah (saja), dan jauhilah Thagut itu”, maka diantara umat itu ada orang-orang yang diberi petunjuk oleh Allah dan ada pula diantaranya orang-orang yang telah pasti kesesatan baginya. Maka berjalanlah kamu dimuka bumi dan perhatikanlah bagaimana kesudahan orang-orang yang mendustakan (rasul-rasul)".}

\section{Pertemuan Kedua: Mengenal Sosok Idola (Ma'rifaturrasul)}

Tujuan dari sesi ini adalah agar peserta didik memahami makna risalah dan rasul, memahami kewajiban beriman kepada rasul, dan mencontoh sang Idola/Rasulullah SAW. Pendekatan yang digunakan adalah games, ceramah dan diskusi. Materi pokok meliputi: Kebutuhan manusia terhadap rasul, Rasul sebagai penyampai risalah, sikap seorang Muslim sebagai bukti cinta Rasul, dan Kewajiban seorang muslim. Seorang muslim wajib beriman kepada seluruh Nabi dan Rasul yang telah diutus oleh Allah swt. Karena sebaik-baik contoh atau idola adalah Rasul. Sebagaimana firman Allah swt. Dalah Al-Qur'an surat al Ahzab [33] ayat 21: 


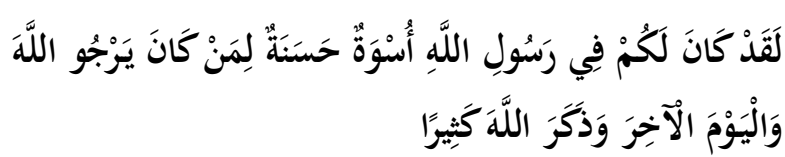

Artinya:

"Sesungguhnya telah ada pada diri Rasulullah uswatun hasanah bagimu, yaitu bagi orang-orang yang mengharap (rahmat) Allah dan (kedatangan) hari kiamat dan dia banyak menyebut Allah”.

Pada kondisi sekarang sedang terjadi krisis idola yang benar bagi para remaja (mahasiswa), sehingga perilaku dan gaya hidup mencontoh apa yang diidolakan, dari pakaian, penampilan dan lain sebagainya.

\section{Pertemuan Ketiga: Al-Qur’an Cahaya Kebenaran}

Tujuan dari sesi ini adalah agar peserta didik mengetahui definisi ma'rifatul Qur'an, mengetahui nama-nama dan karakteristik Al-Qur'an, memahami fungsi Al-Qur'an dan akhlak terhadapnya, termotivasi untuk membaca, mempelajari dan mengamalkan Al-Qur'an. Pendekatan penyampaian materi adalah dengan ceramah dan diskusi. Materi pokok meliputi: isi atau kandungan Al-Qur'an, Kemu'jizatan Al-Qur'an, dan Perbedaan Al Qur'an dan kitab suci yang lain. Al-Qur'an sebagai kitab suci orang Islam banyak yang tidak mengimaninya, sehingga mereka tersesat. Allah berfirman dalam al Qur'an surat An Nisa [4] ayat 136:

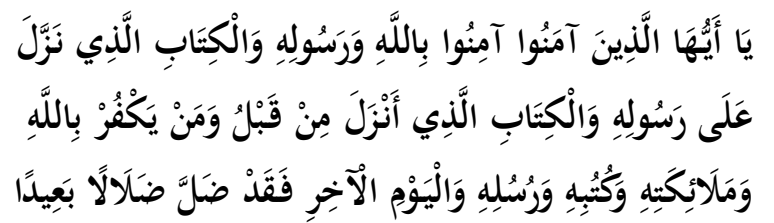

Artinya:

"Wahai orang-orang yang beriman, tetaplah beriman kepada Allah dan Rasul-Nya dan kepada kitab yang Allah turunkan kepada RasulNya serta kitab yang Allah turunkan sebelumnya. Barangsiapa yang kafir kepada Allah, malaikat-malaikat-Nya, kitab-kitab-Nya, rasulrasul-Nya, dan hari kemudian, maka sesungguhnya orang itu telah sesat sejauh-jauhnya”.

\section{Pertemuan Keempat: Ma'rifatul Insan}

Tujuan dari sesi ini adalah agar peserta mengetahui makna Ma'rifatul Insan, mengetahui kecenderungan sifat-sifat seorang insan, memahami cara untuk mengenalikan sifat-sifat tercela, dan memahami cara untuk menumbuhkan sifat-sifat terpuji dan mengamalkan dalam kehidupan. Pendekatan penyampaian materi dengan games, ceramah dan diskusi.
Materi pokok meliputi: Keistimewaan manusia, Kelemahan manusia, Iman dan manifestasinya dalam kehidupan. Manusia sebagai ciptaan Allah, ada yang belum tahu arah dan tujuan. Ada manusia yang beriman dan beramal shaleh sesuai dengan keimanannya itu, sda yang beriman tapi banyak melakukan pembangkangan terhadap kekuasaan Allah SWT., ada juga secara lahir mengaku beriman dan berusaha membuktikan kepada orang banyak bahwa mereka beriman dengan melakukan sebagian ibadah, padahal sesungguhnya mereka tidak ber-iman. Dengan demikian, mereka belum memahami tujuan hidup, padahal Allah swt. Berfirman dalam AlQur'an surat Adz Dzariyat [51] ayat 56:

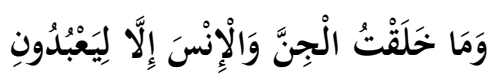

Artinya:

"Dan aku tidak menciptakan jin dan manusia melainkan supaya mereka mengabdi kepada$\mathrm{Ku}$.

\section{Pertemuan Kelima: Hidup Islami}

Tujuan dari sesi ini adalah agar peserta didik memahami konsekuensi sebagai Muslim, termotivasi untuk mengamalkan ajaran Islam dalam kehidupan sehari-hari. Pendekatan penyampaian materi dilakukan dengan ceramah dan diskusi. Materi meliputi: Tujuan Dakwah Islam, Pengertian Amar Ma'ruf, Pengertian Nahi Munkar, dan Amal dan Perjuangan. Hal yang paling penting adalah bagaimana agar nilainilai Islam yang ditanamkan kepada peserta didik kemudian ditindak lanjuti dengan perilaku yang Islami dalam kehidupan sehari-hari. Dimulai dari diri sendiri, keluarga, kemudian masyarakat sekitar, sebagaimana Allah telah berfirman pada surat Ali Imran [3] ayat 110:

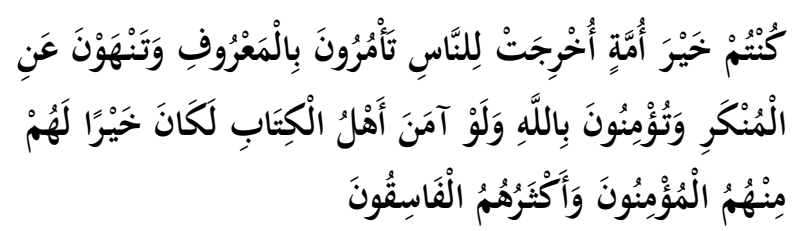

Artinya:

"Kamu (ummat Islam) adalah ummat terbaik yang dilahirkan untuk manusia, (karena kamu) menyuruh (berbuat) yang ma'ruf dan mencegah dari yang munkar dan beriman kepada Allah. Sekiranya ahli kitab beriman, tentulah itu lebih baik bagi mereka. Diantara mereka ada yang beriman, namun kebanyakan mereka adalah orang-orang fasik”.

Dalam ayat di atas Allah memuliakan ummat Islam karena selalu mengajak kepada kebajikan dan 
mencegah kemunkaran, akan tetapi kebanyakan dari mereka berbuat fasik. Allah SWT. juga berfirman dalam surat At Tahrim [66] ayat 6:

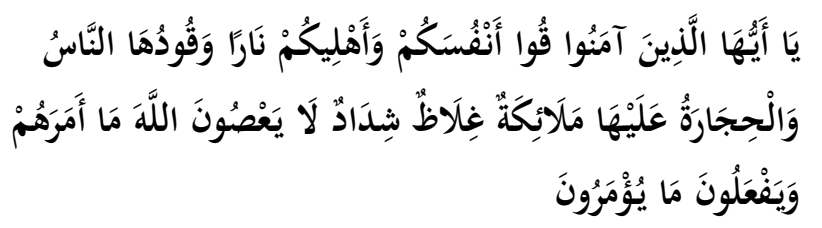

Artinya:

Hai orang-orang yang beriman, peliharalah dirimu dan keluargamu dari api neraka yang bahan bakarnya adalah manusia dan batu, penjaganya malaikat-malaikat yang keras dan kasar dan yang tidak durhaka kepada Allah terhadap apa yang Dia perintahkan kepada mereka dan selalu mengerjakan apa yang diperintahkan".

Allah memerintahkan kepada ummat-Nya agar senantiasa menjaga diri (Ibda' binafsi) dan keluarga. Dakwah dimulai dari diri sendiri dan keluarga agar terhindar dari siksaan api neraka.

\section{Pertemuan Keenam: Cakrawala berpikir Intelektual (Al-Ilmu)}

Tujuan dari sesi ini adalah agar peserta didik memahami sifat dan kualitas ilmu manusia dan ilmu Allah, mengetahui jalan-jalan turunnya ilmu Allah, memahami pentingnya mencari ilmu Allah, dan termotivasi untuk mencari dan memahami ilmu Allah. Pendekatan dalam penyampaian materi dilakukan dengan ceramah dan diskusi. Materi pokok meliputi: Pengertian Ilmu, Klasifikasi Ilmu, Konsep Tauhid sebagai Landasan Berpijak, Kewajiban Menuntut Ilmu, dan Kriteria Ilmu Yang Berguna. Allah telah memerintahkan agar dalam berbuat harus berdasarkan ilmu, larangan mengikuti sesuatu yang tidak berdasarkan ilmu. Dalam al Qur'an surat $\mathrm{Al}$ Isra [17] ayat 36:

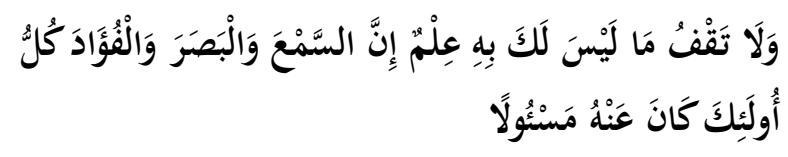

Artinya:

"Dan janganlah kamu mengikuti sesuatu yang tidak kamu ketahui. Karena pendengaran, penglihatan, dan hati, semua itu akan diminta pertanggungjawabannya”.

\section{Pertemuan Ketujuh: Pergaulan Muda-mudi}

Tujuan dari sesi ini adalah agar peserta didik memahami makna dan hakekat pergaulan yang Islami, dan mengetahui pengaruh positif dan negatif dari pergaulan. Penyampaian materi dilakukan dengan pendekatan ceramah dan diskusi. Materi pokok sesi ini meliputi: Konsep Pergaulan dalam Islam, Adab makan dan minum, Kajian QS. An Nur: 30-31 dan QS. Al Isra: 32, Akibat Free sex, Narkoba, judi, mencuri, dan perilaku buruk lainnya, Komitmen dalam pergaulan, dan Berpikir cerdas.

\section{Pertemuan Kedelapan: Adab Berbusana Muslim}

Tujuan dari sesi ini adalah agar peserta didik memahami makna dan maksud dari berbusana yang Islami, mengetahui manfaat dan pentingnya berbusana muslim, dan peserta berkomitmen untuk berbusana muslim yang Islami. Penyampaian materi dilakukan dengan pendekatan ceramah dan diskusi. Materi pokok sesi ini adalah: Maksud dan tujuan syariat Islam dalam berbusana muslim, Manfaat dan pentingnya berbusana muslim, Dampak/akibat tidak berbusana muslim yang Islami, dan Wujud anak berbakti kepada orang orangtua. Allah berfirman dalam al Qur'an surat An Nur[24] ayat 31:

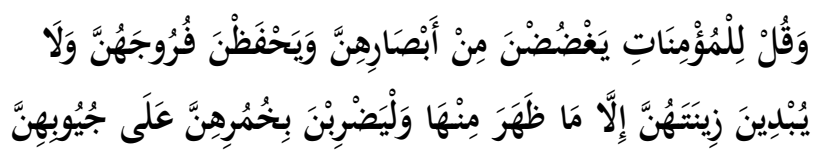

Artinya:

Dan katakanlah kepada para perempuan yang beriman, agar mereka menjaga pandangannya, dan memelihara kemaluannya, dan janganlah menampakkan perhiasannya (auratnya), kecuali yang (biasa) terlihat. Dan hendaklah mereka menutupkan kain kerudung kedadanya.

\section{Pertemuan Kesembilan: Bercinta dan bersaudara karena Allah}

Tujuan dari sesi ini adalah agar peserta didik memahami makna dan hakikat Ukhuwah Islamiyah, mengetahui perbedaan Ukhuwah Islamiyah dan Ukhuwah Jahiliyah, mengetahui hal-hal yang menguatkan ukhuwah dan buah dari Ukhuwah Islamiyah, dan termotivasi untuk mengamalkan hal-hal yang menuju kepada Ukhuwah Islamiyah dalam kehidupan. Pendekatan dalam penyampaian materi dengan cara games, ceramah dan diskusi. Materi pokok meliputi: Pengertian Ukhuwah (Kajian QS. Al Hujurat ayat 10 dan Ali Imran ayat 103), Makna Cinta (Kajian QS. At Taubah ayat 24), Pengertian Ukhuwah dalam Islam, Range of Ukhuwah Islamiyah, Keuta-maan Ukhuwah Islamiyah, Syaratsyarat Ukhuwah Islamiyah, dan Cara mempererat Ukhuwah Islami-yah. Allah memerintahkan agar selalu berpegang teguh pada agama Allah dan jangan 
bercerai berai. Ummat Islam hukumnya wajib menjaga Ukhuwah Islamiyah.

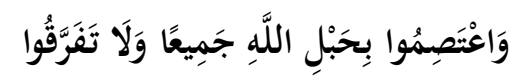

Artinya:

"Dan berpegang teguhlah kamu semuanya pada tali (agama) Allah, dan janganlah kamu bercerai berai”. (Ali Imran [3] ayat 103)

\section{Pertemuan Kesepuluh: Media Sosial}

Tujuan dari sesi ini adalah agar peserta didik dapat lebih bijak dalam memanfaatkan Media Sosial (Medsos) dan mampu menyikapi Ghozwul Fikri Haters. Pendekatan penyampaian materi ini adalah dengan diskusi. Materi pokok pada sesi ini adalah bijak dalam Medsos dan Sikap terhadap Ghozwul Fikri (Medsos). Menggunakan teknologi tidak ada larangan dalam agama, akan tetapi menggunakan teknologi tersebut secara bijak adalah suatu yang wajib dilakukan oleh manusia. Tidak digunakan untuk memfitnah bahkan sampai membunuh, baik membunuh dalam bentuk fisik maupun karakter lewat teknologi yang semakin maju. Dalam kaidah ushul fiqh disebutkan:

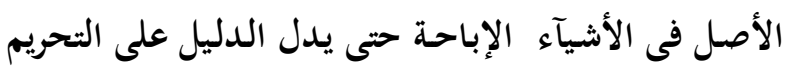

Artinya:

"Pada asalnya bahwa segala sesuatu itu dibolehkan sampai ada dalil yang mengharamkannya."

\section{SIMPULAN $^{1}$}

Paper ini berisi konsep pendidikan karakter keagamaan secara Islami yang diperuntukkan bagi mahasiswa program studi Akuntansi di Universitas Muhammadiyah Yogyakarta selaku calon akuntan di masa mendatang. Isu ini penting dikaji mengingat terjadi berbagai masalah yang mencuat seputar perilaku akuntan, baik perilaku yang berkaitan dengan praktik bisnis profesional, seperti perilaku curang pada saat pelaporan keuangan, dan juga yang tidak secara langsung berkaitan dengan praktik bisnis profesional, seperti: sekularisme ilmu dan agama, kemunculan faham Islam radikal di lingkungan

\footnotetext{
${ }^{1}$ CATATAN: Tugas Mutaba'ah Yaumiyah mulai materi ke-2 s/d 10, Tujuan: Peserta membiasakan Ibadah wajib dan sunnah dan Peserta membiasakan Jamaah Shalat wajib. Metode Pendekatan: Penugasan. Materi meliputi: Shalat wajib berjamaah, Tadarus Al Qur'an dan Hafalan, Shalat Tahajud, Shalat Dhuha, Puasa Senin dan Kamis, serta Membiasakan Berbusana Muslimah.
}

perguruan tinggi, dan fenomena krisis moral (pergaulan bebas, prostitusi, perjudian, pencandu narkotika, dan lain sebagainya). Pada paper ini dikemukakan kelemahan model PAI terdahulu dan kemudian dirumuskan kembali model PAI yang disesuaikan dengan permasalahan kekinian yang dihadapi. Baik model program PAI dan materi yang disampaikan didasarkan kepada konsep pendidikan karakter keagamaan oleh ulama Islam dan dikuatkan dengan anjuran dari nash-nash di Al-Qur'an.

Paper ini diharapkan memberikan kontribusi pada aspek teoritis, yakni sebagai bahan kajian dan diskusi dimasa mendatang dalam mendesain konsep Islamisasi pendidikan yang berideologi religius Islam. Dalam aspek praktis, dari apa yang disampaikan di dalam paper ini, semoga dapat menjadi rujukan dalam membuat suatu program atau kegiatan pendidikan karakter dengan berdasar pada kajian religius ajaran agama, khususnya Islam.

Paper ini memiliki keterbatasan, yakni konteks desain pendidikan karakter keagamaan berbasis Islam ini dibuat dengan mengacu kepada permasalahan yang muncul di lingkungan prodi Akuntansi UMY. Oleh karenanya, desain ini bisa saja tidak cocok jika digunakan oleh institusi di luar lingkungan UMY, mengingat setiap institusi, khususnya di lembaga publik semacam perguruan tinggi, biasanya memiliki karakteristik khas yang berbeda-beda (Sofyani dan Akbar, 2013; 2014). Namun demikian, model ini dapat digunakan sebagai bahan acuan untuk mengembangkan program serupa di lingkungan institusi lain. Berangkat dari paper ini, selanjutnya dapat dilakukan penelitian di masa mendatang terkait bagaimana dampak dari adanya program ini, apakah bernilai tambah atau tidak?, evaluasi program PAI, dan pengujian secara empiris dalam konteks perilaku etis mahasiswa sebelum dan setelah mengikuti program ini dengan pendekatan desain eksperimen.

\section{DAFTAR PUSTAKA}

Al-Qur'an Al-Karim.

Akhwan, M. 2014. Pendidikan Karakter: Konsep dan Implementasinya dalam Pembelajaran di Sekolah/Madrasah. El-Tarbawi, 7 (1), 61-67.

Amernic, J. dan R. Craig. 2004. Reform of Accounting Education in the Post-Enron Era: Moving Accounting 'Out of the Shadows, Abacus, 40 (3), 342-378.

Arif, M. 1985. Toward the Shari'ah Paradigm of Islamic Economics: The Beginning of Scientific Revolution. The American Journal of Islamic Social Sciences, 2 (1), 79-99. 
Cohen, J. R. dan N. M. Bennie. 2006. The Applicability of a Contingent Factors Model to Accounting Ethics Research, Journal of Business Ethics, 68, 1-18.

Dunk, A. S. 1993. The effect of budget emphasis and information asymmetry on the relation between budgetary participation and slack. Accounting review, 400-410.

Fisher, D. G., D. L. Swanson dan J. J. Schmidt. 2007. Accounting Education Lags CPE Ethics Requirements: Implications for the Profession and a Call to Action. Accounting Education, 16 (4), 345-363.

Fishbein, M., dan I. Ajzen. 1974. Attitudes towards objects as predictors of single and multiple behavioral criteria. Psychological Review, 81 (1), 59-74.

Fishbein, M., dan I. Ajzen. 1975. Belief, attitude, intention, and behavior: An introduction to theory and research. Reading: AddisonWesley.

Jones, T. M. 1991. Ethical Decision Making by Individuals in Organizations: An IssueContingent Model. A cademy of Management Review, 16, 366-395.

Juanda. 2005. Evaluasi Pelaksanaan Program Pendampinya Agama Islam di Universitas Muhamadiyah Yogyakarta. Tesis, Universitas Muhamadiyah Yogyakarta

Khilmiyah, A. 2013. Perbandingan Keterampilan Intrapersonal dan Interpersonal Berbasis Pendidikan Karakter Siswa Sekolah Dasar Negeri Kasihan Bantul. Afkaruna: Jurnal Ilmu-Ilmu Keislaman, 9 (1), 50-64.

Low, M., H. Davey dan K. Hooper. 2008. Accounting Scandals, Ethical Dilemmas and Educational Challenges. Critical Perspectives on Accounting, 19, 222-254.

LP3M UMY. 1999. Judul tidak diketahui, Jurnal IDEA, 5.

Majelis Ulama Indonesia. 2004. Keputusan Majelis Ulama Indonesia Nomor 1 Tahun 2004 Tentang Bunga (Interest/Fa'idah).

Mazereeuw, C., J. Graafland dan M. Kaptein. 2014. Religiosity, CSR Attitudes, and CSR Behaviour: An Empirical Study of Executives' Religiosity and CSR. Journal of Business Ethics, 123, 437-459.

Merchant, K. A. 1985. Budgeting and the propensity to create budgetary slack. Accounting, Organizations and Society, 10 (2), 201-210.

Murphy, P. R., dan B. W. Mayhew. 2009. The Impact of Ethics Education on Reporting Behavior. Journal of Business Ethics, 86 (3), $397-416$.
Pusat Pengkajian dan Pengembangan Ekonomi Islam. 2009. Ekonomi Islam. Jakarta: Rajawali Press.

Sinetar. 2000. Spiritual Intellegence. New York: Orbis Book.

Sofyani, H. dan R. Akbar. 2013. Hubungan Faktor Internal Institusi dan Implementasi Sistem Akuntabilitas Kinerja Instansi Pemerintah (SAKIP) di Pemerintah Daerah. Jurnal Akuntansi dan Keuangan Indonesia, 10 (2), 184205.

Sofyani, H. dan R. Akbar. 2015. Hubungan Karakteristik Pegawai Pemerintah Daerah dan Implementasi Sistem Pengukuran Kinerja: Perspektif Ismorfisma Institusional. Jurnal Akuntansi \& Auditing Indonesia, 19 (2), 153173.

Sofyani, H. dan Y. D. Pramita. 2013. Otoritas Atasan, Retaliasi dan Locus of Control Sebagai Faktor-faktor yang Memengaruhi Perilaku Manipulasi Laporan Realisasi Anggaran. Jurnal Reviu Akuntansi dan Keuangan, 3 (2), 427-436.

Stevens, D. E. 2002. The effects of reputation and ethics on budgetary slack. Journal of Management Accounting Research, 14 (1), 153-171.

Triyuwono, I. 2012. Akuntansi Syariah; Perspektif, Metodologi, dan Teori. Edisi Kedua. Jakarta: Rajawali Press.

Weber, J. 2006. Implementing an Organizational Ethics Program in an Academic Environment: the Challenges and Opportunities for the Duquesne University Schools of Business. Journal of Business Ethics, 65, 23-42.

Yaya, R., A. E. Martawireja, dan A. Abdurahim. 2009. Akuntansi Perbankan Syariah Teori dan Praktik Kontemporer. Jakarta: Salemba Empat. 